7-1976

\title{
Certainty of Arrest and Crime Rates for Major Felonies: Research Note
}

William C. Bailey

Cleveland State University, w.bailey@csuohio.edu

Follow this and additional works at: https://engagedscholarship.csuohio.edu/clsoc_crim_facpub

Part of the Criminology Commons, and the Social Control, Law, Crime, and Deviance Commons How does access to this work benefit you? Let us know!

Publisher's Statement

(c) 1976 Sage Publications

\section{Original Citation}

Bailey, W. C. (1976). Certainty of Arrest and Crime Rates for Major Felonies: A Research Note. Journal of Research in Crime and Delinquency, 13, 2, 145-154.

\section{Repository Citation}

Bailey, William C., "Certainty of Arrest and Crime Rates for Major Felonies: Research Note" (1976). Sociology \& Criminology Faculty Publications. 68.

https://engagedscholarship.csuohio.edu/clsoc_crim_facpub/68

This Article is brought to you for free and open access by the Sociology \& Criminology Department at EngagedScholarship@CSU. It has been accepted for inclusion in Sociology \& Criminology Faculty Publications by an authorized administrator of EngagedScholarship@CSU. For more information, please contact library.es@csuohio.edu. 


\title{
CERTAINTY OF ARREST AND CRIME RATES FOR MAJOR FELONIES: A RESEARCH NOTE
}

\author{
William C. Bailey, Cleveland State University
}

This article was originally published in:

Bailey, William C. (1976). Certainty of Arrest and Crime Rates for Major Felonies: A Research Note. Journal of Research in Crime and Delinquency, 13, 145-154.

Post-print standardized by MSL Academic Endeavors, the imprint of the Michael Schwartz Library at Cleveland State University, 2013

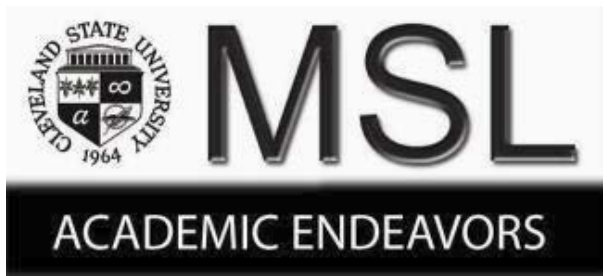




\title{
Certainty of Arrest and Crime Rates for Major Felonies: A Research Note
}

\author{
William C. Bailey \\ The Cleveland State University
}

\begin{abstract}
A recent investigation by Tittle and Rowe (1974) examining the deterrent effect of the certainty of arrest on felony rates in Florida is briefly summarized and critiqued. Examination shows their analysis to suffer from serious theoretical and methodological limitations. To extend their investigation and thus better understand the deterrent effect of arrest we examine the relationship between arrest rates and offense rates for cities and counties of Florida for seven major felonies. Analysis lends general support to the deterrence argument, but shows that the effect of arrest is not uniform for each offense, with different levels of arrest (certainty of apprehension) required to reduce rates for different crimes.
\end{abstract}

N A RECENT ARTICLE, Tittle and Rowe (1974) provide a further examination of the deterrent effect of certainty of punishment on offense rates. In an attempt to extend previous analyses they examine (1) the effect of arrest clearance rates on offense rates, rather than focusing upon imprisonment as have others (Gibbs, 1968; Tittle, 1969; Chiricos and Waldo, 1970; Logan, 1972; Bailey, Martin and Gray, 1974), (2) the certainty-rate relationship for smaller and presumably more homogeneous geographic units (cities and counties) than in previous analyses which have focused upon states (Gibbs, 1968; Tittle, 1969; Chiricos and Waldo, 1970; Logan, 1972; Bailey, Martin and Gray, 1974), and (3) the possible spuriousness of the certainty-rate relationship by controlling for a number of socioeconomic and demographic factors associated with crime.
The first step of their analysis was to construct scatter diagrams locating each unit (cities and counties) simultaneously at the intersection of the certainty-felony rate coordinates. Inspection revealed the association to be nonlinear, with a tipping point being reached at a 30 percent clearance level. To illustrate, the association between arrest and rate was found to be $r=-.65(\mathrm{P}<.05)$ for counties and $r=-.19(\mathrm{P}<.05)$ for cities with populations of 2,500 or more. For counties with clearance rates above 30 percent, however, the correlation was $r=-.58$, while $r=-.13$ for those below this level. Similarly, for cities the respective coefficients are -.48 and .19 . These findings remained basically unaltered when a number of socioeconomic and demographic factors were introduced as control variables. ${ }^{1}$ Examination of median offense rates of units above and below the 30 percent level 
lent further support to the notion that a tipping effect occurs at this level. For counties, the total felony rate (per 1,000 persons) is 32.5 and 11.7 , respectively, for units below and above this mark. Median figures for cities are 33.0 and 17.8 , respectively. These findings, they argue, indicate "that there is a critical level $/ 30 \% /$ that certainty must reach before there is a noticeable change in volume of crime" (458). They go on to say that their data clearly suggest that legal sanctions can no longer be ignored as deterrents to crime, and "perhaps the missing link" in current etiological thinking in criminology is the "fear of sanction/s/" (461).

While Titrle and Rowe should be commended for attempting to build upon previous deterrence analyses, their investigation suffers from a few serious limitations. First, they solely focus upon the certainty-rate relationship for one year (1971) in the state of Florida. It thus remains unclear whether their findings may be generalized to other years and areas of the country. Second, they fail to examine the certainty-rate question for individual felonies. Rather, they simply examine the relationship between cities' and counties' total felony rates and the proportion of total felonies cleared by arrest. Accordingly, it also remains unclear how well their findings may be generalized to different types of offenses. In this respect, it is of interest to note that Tittle and Rowe indicate early in their dis-

1. The socioeconomic and demographic variables Titrle and Rowe considered are: (1) \% male population, (2) \% population aged 15-24, (3) \% male population aged $15-24,(4) \%$ population age 65 and over, (5) size of city or $\%$ of county living in cities 20,000 and over, (6) \% women in the labor force, (7) \% population in poverty, (8) \% Negro population, (9) \% nonwhite population, (10) median education, (11) interquartile range of income. cussion that previous deterrence investigations (including Tittle's, 1969) have found that the effect of certainty varies by "the type of norm /offense/ in question" (455). They neglect to take this factor into consideration in their analysis however, nor do they even consider this possibility in interpreting their findings. ${ }^{2}$ In short, Tittle and Rowe's analysis neither permits a clear understanding of the effect of arrest on different felonies, nor the level of clearance required to reduce rates for difference crimes.

\section{The Present Investigation}

The research reported here is both a partial replication and extension of Tittle and Rowe's analysis. Like them, we examine the relationship between total felony rates and total felony arrest rates for counties and cities of Florida but for the year 1972. By comparing our findings for Florida for 1972 with theirs for 1971 it will be possible to at least partially examine one of the limitations noted above. Second, by considering each major offense separately (homicide, rape, robbery, assault, breaking and entering, larceny, auto theft) it will be possible to examine the deterrent effect of arrest for each crime, and the level of arrest required to reduce rates for each offense. Third, we introduce into the analysis a measure of police strength (number of police per 1000 population) as a control variable in examining the certainty-offense rate relationship. ${ }^{3}$ While Tittle and

2. For a comprehensive discussion of the differential impact of legal sanctions by offense and type of offender see: Andenaes (1974), Zimring and Hawkins (1974), Zimring (1971), Chambliss (1967).

3. Arrest, offense rate and police personnel figures were secured from 1972 Annual Report: Crime In Florida, Florida Department of Law Enforcement; Tallahassee, Florida. Tittle and Rowe took offense and arrest clearance rate figures from the 1971 annual Florida report. 
Rowe found this relationship to be generally unaffected when a number of socioeconomic and demographic variables were examined, they failed to consider how police manpower may affect both clearance rates and offense rates. To illustrate, a community with a large number of police per capita may be able to achieve a higher arrest clearance rate than a community with few police. At the same time, however, communities with a large number of police per capita may also have unexpectedly high reported offense rates (at least for some crimes) due to the fact that; (1) with a greater number of police, all other things being equal, more crimes will probably be detected first hand by the police, i.e., fewer crimes will go unnoticed and unrecorded, and (2) with a greater number of police, police visibility and availability would tend to increase, which may result in a greater willingness of victims of crime and others to report offenses to the authorities. Conversely, a community with few police per capita may have a low arrest clearance rate due to a lack of resources but a lower than expected reported crime rate due to; (1) the police not detecting first hand as many offenses as they might with more personnel, and (2) possibly less reporting of crimes by citizens to the authorities because of their lower visability and possible effectiveness. In short, while for both high and low police per capita communities the arrest clearance rate-offense rate relationship may be in the hypothesized negative direction, the level of police manpower may tend to distort this relationship and drive the certaintyrate correlation in a positive direction.

In addition, the level of police manpower may, of course, affect of- fense rates quite apart from its effect on arrest clearance rates. In line with the deterrence argument, simply the greater visibility of the police in communities with a high per capita of police (and the assumed greater likelihood of detection and arrest of would-be offenders) would have the effect of reducing offense rates. Conversely, one would expect just the opposite to result in communities with a lower per capita of police. Unfortunately, Tittle and Rowe failed to take police strength into consideration in their investigation so it is simply not possible to say how this factor may have affected their findings.

Finally, in this investigation we use as our measure of the certainty of arrest the number of reported arrests for each felony divided by the number of such felonies reported by the police. This procedure resulted in a certainty value for each unit (city, county), for each offense, ranging from 0.0 to unity $(1.00)$. A value of 0.0 would indicate that there were no arrests for the offense in question while a value of 1.00 would indicate an equal number of offenses and arrests. While this measure of certainty suffers from some limitations (it does not rake into consideration what happens after arrest, i.e., release, prosecution, plea bargaining, conviction, sentencing, etc.) it would seem preferable to Tittle and Rowe's use of arrest clearance percentages which were compiled by the police as an indicator of certainty. They note that arrest clearance rates (which are often used as a measure of police efficiency), because they are compiled by the police and are a product of police discretion, are subject to distortion. They argue, however, that the data are probably not greatly contaminated, and even if they are, "such 
bias would seem to be distributed throughout the various police departments so that the validity of a study which examines internal variations in the entire body of data... would be unaffected" (456).

While they may be correct that police clearance rate figures issued by police departments in Florida are not "greatly contaminated," they present no evidence to support this claim. (In fact, Tittle (1975) later concludes that these data are proably terribly biased, which quite likely is responsible for these figures being dropped from the Crime In Florida annual report.) Similarly, they present no evidence to support their claim that even if such distortion does exist, "such bias would seem to be distributed [equally] throughout the various police departments" (456). While we also lack the necessary Florida data for police departments to systematically address this question, we cannot help but be skeptical about their argument when Tittle and Rowe's data show arrest clearance rates for cities ranging from the extremes of less than five percent to 100 percent.

\section{Methods and Procedures}

To address the above questions, our analysis consisted of three stages. First, cities and counties were divided into four groupings by level of arrest for each felony $(0-25 \%, 26-50 \%, 51-$ $75 \%, 76-100 \%$ ) with average offense rates computed for each grouping. In line with deterrence theory, we would expect a decrease in rate as the level of certainty increases. Second, through a correlation analysis we examined the effect of arrest on rates for each felony at certainty levels of $0-10 \%, \quad 10.1-20 \%, 20.1-30 \%$ .. 80.1-90\% and $90.1 \%$ and over. Our concern here was to determine the critical level of arrest required to reduce rates for each offense and to test how well the 30 percent figure Tittle and Rowe suggest applies to each crime. ${ }^{4}$ Third, to examine the possible spuriousness of the relationshp between arrest rates and offense rates, and the influence of police strength on these variables, partial correlations were computed between arrests and offense rates for each felony, controlling for the number of police per 1000 population. By comparing the zero-order and partial correlations between arrest and offense rates, we will be able to examine to what extent the certainty-rate relationship is a statistical artifact resulting from a failure to consider police strength as a third variable.

Before reporting the results of our analysis, it would seem of value to briefly reiterate a point discussed at some length by Titlle and Rowe and previous deterrence investigators (Tittle, 1969; Chiricos and Waldo, 1970; Logan, 1971, 1972; Bailey, et al., 1971; Bailey, et al., 1974) concerning the possible spuriousness of correlations that result when examining independent and dependent variables that are ratios containing a common term (arrest clearance rate $=$ \# of arrests/ \# crimes known to the police; offense rate $=$ \# crimes known to the policel population). Since the denominator of our inde-

4. In the absence of any established theoretical guidelines for dividing cities and counties into groups by level of arrest, we have arbitrarily chosen the intervals that appear in Tables 1-3. Here our intention was simply to explore the certainty-rate relationship under varying conditions of arrest. Inspection of Tables 1-3 reveals that in some cases means, medians, and product moment correlations were not computed due to small subsample sizes $(\mathrm{n}<5$ for Table 1, and $\mathrm{n}<10$ for Tables 2-3). As with cutting points for levels of certainty, cutting points for $n$ sizes sufficiently large to compute test statistics were also selected arbitrarily. 
pendent variable and the numerator of our dependent variable contain a common term, it has been argued that this would automatically produce a negative association between the two variables (Chiricos and Waldo, 1970). As pointed out in a number of recent investigations, however, this is not a relevant concern when "ratios containing a common term are theoretically meaningful as ratios," as they are here and in Tittle and Rowe's $(1974,457)$ investigation. In addition, the indexical artifact issue is only of concern when the elements of the ratios are not related, which of course, is not the case here nor in Tittle and Rowe's investigation (Logan, 1971, 1972; Bailey, et al., 1971; Bailey, et al., 1974).

\section{Results}

Table I reports average rates for total felonies and individual offenses for cities and counties of Florida by level of arrest.

For total felonies, examination shows mean and median offense rates for both cities and counties to exceed average rates for their respective units until arrest levels exceed 50 percent. After this point, rates drop substantially for counties and only slightly for cities, but with a more substantial reduction in city rates occurring after certainty exceeds 75 percent. A similar pattern occurs for larceny and auto theft with city and county rates dropping below the average for their respective units when arrests exceed 50 percent, and with an even more pronounced reduction occurring after certainty reaches 75 percent. The same general pattern also occurs for breaking and entering, but with a reduction in city and county rates beginning after a 25 percent level is reached.

A slightly different pattern occurs for the remaining offenses. For robbery, city and county (median only) rates do not fall below the average for their respective units until arrests exceed 75 percent, while the mean rate for counties drops below the average after the 50 percent mark. Consistent with deterrence theory, however, robbery rates continue to decline for cities and counties after the .50 level.

In contrast, for rape and murder, mean and median rates for cities exceed the state's average at all three levels beyond the $0-25$ percent inter-

TABI.E 1

MLAN AND MEDIAN OFFENSE RATES FOR CITIES AND COUNTIES IN FLORIDA BY L.EVELL OF ARREST, 1972

\begin{tabular}{|c|c|c|c|c|c|c|c|c|c|c|c|}
\hline \multirow[b]{2}{*}{ offense } & \multicolumn{5}{|c|}{$\underline{\text { Gitics }}$} & \multicolumn{6}{|c|}{ countres } \\
\hline & & $\Delta 11(0-100 \%)$ & $0-258$ & $26-50 \%$ & $51-75 \%$ & $76-2007$ & Alus(0-10005) & $0-25 \%$ & $26-50 \%$ & $51-75 \%$ & $-76-100 \%$ \\
\hline Prurder & $\begin{array}{l}\text { mear } \\
\text { medi ian }\end{array}$ & $\begin{array}{l}.079 \\
0.0\end{array}$ & .014 & 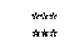 & .2299 & .175 &. .277 & $\begin{array}{l}.93 \\
0.0\end{array}$ & $\underset{\substack{x \rightarrow t \\
x \rightarrow \infty}}{x \rightarrow \infty}$ & $\begin{array}{l}.193 \\
.155\end{array}$ & $\begin{array}{l}.147 \\
.113\end{array}$ \\
\hline Forcible Rape & $\underset{\substack{\text { mean } \\
\text { med zan }}}{\text { nan }}$ & $\begin{array}{l}.142 \\
.064\end{array}$ & $\begin{array}{l}.058 \\
0.0\end{array}$ & $\begin{array}{r}.359 \\
.344\end{array}$ & $\begin{array}{l}.219 \\
.281\end{array}$ & $\begin{array}{l}.263 \\
.286\end{array}$ & $\begin{array}{l}.172 \\
.14141\end{array}$ & $\begin{array}{l}.069 \\
0.0\end{array}$ & $\begin{array}{l}.234 \\
.231\end{array}$ & $\begin{array}{l}.249 \\
.273\end{array}$ & $\begin{array}{l}.156 \\
.134\end{array}$ \\
\hline Robbery & $\begin{array}{l}\substack{\text { mean } \\
\text { med Ian }} \\
\text { ad }\end{array}$ & $\begin{array}{l}1,048 \\
.66\end{array}$ & $\begin{array}{l}.920 \\
.426\end{array}$ & $\begin{array}{l}1.51 \\
1.04\end{array}$ & $\begin{array}{l}1.15 \\
.829\end{array}$ & $\begin{array}{l}.591 \\
.525\end{array}$ &. & $\begin{array}{l}.526 \\
.185\end{array}$ & $\begin{array}{l}1.164 \\
1,186\end{array}$ & $\begin{array}{l}.563 \\
.602\end{array}$ & $\begin{array}{l}.365 \\
.288\end{array}$ \\
\hline Assault & 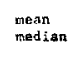 & $\begin{array}{l}2.59 \\
1.47\end{array}$ & $\begin{array}{r}2.47 \\
.72\end{array}$ & $\begin{array}{l}3.94 \\
3.03\end{array}$ & $\begin{array}{l}2.79 \\
1.50\end{array}$ & $\begin{array}{l}1.18 \\
.607\end{array}$ & $\begin{array}{l}2.42 \\
2.22\end{array}$ & 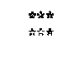 & $\begin{array}{l}3.00 \\
2.93\end{array}$ & $\begin{array}{l}2.69 \\
2.32\end{array}$ & $\begin{array}{l}1.65 \\
1.25\end{array}$ \\
\hline Breaktag \& Entering & $\begin{array}{l}\text { meon } \\
\text { median }\end{array}$ & $\begin{array}{l}12.09 \\
11.12\end{array}$ & $\begin{array}{l}12.97 \\
12.09\end{array}$ & $\begin{array}{l}9.12 \\
7.31\end{array}$ & $\begin{array}{l}4.35 \\
3.92\end{array}$ & 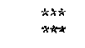 & $\begin{array}{l}9.96 \\
9.45\end{array}$ & $\begin{array}{l}\begin{array}{l}11.80 \\
12,89\end{array} \\
1\end{array}$ & $\begin{array}{l}6.40 \\
5.74\end{array}$ & $\lim _{x \rightarrow * ;}$ & 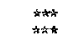 \\
\hline Larceny & $\begin{array}{l}\text { mean } \\
\text { med dan }\end{array}$ & $\begin{array}{l}12.42 \\
11.80\end{array}$ & $\begin{array}{l}13.28 \\
12.20\end{array}$ & 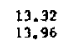 & $\begin{array}{l}12.05 \\
11.49\end{array}$ & $\begin{array}{l}9.29 \\
6.90\end{array}$ & $\begin{array}{l}8.62 \\
7.69\end{array}$ & $\begin{array}{l}7.60 \\
7.36\end{array}$ & $\begin{array}{l}11.28 \\
12.49\end{array}$ & $\begin{array}{l}5.26 \\
3.14\end{array}$ & $\begin{array}{l}1.97 \\
1.65\end{array}$ \\
\hline Aueo Thefe & 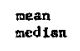 & $\begin{array}{l}2.24 \\
1.72\end{array}$ & $\begin{array}{l}2.38 \\
1.76\end{array}$ & $\begin{array}{l}2.32 \\
2.00\end{array}$ & $\begin{array}{l}1.34 \\
1.12\end{array}$ & $\begin{array}{l}2.09 \\
1.27\end{array}$ & $\begin{array}{l}1.73 \\
1.24\end{array}$ & $\begin{array}{l}2.35 \\
2.03\end{array}$ & $\begin{array}{l}1 ., 77 \\
1.63\end{array}$ & .9455 & $\begin{array}{l}.450 \\
.473\end{array}$ \\
\hline Tota: Felonise & $\begin{array}{l}\text { mean } \\
\text { rediar: }\end{array}$ & $\begin{array}{l}30.61 \\
27.17\end{array}$ & $\begin{array}{l}31.24 \\
28.24\end{array}$ & $\begin{array}{l}\begin{array}{l}33.01 \\
28.93\end{array} \\
28.9\end{array}$ & $\begin{array}{l}29.45 \\
32.74\end{array}$ & $\begin{array}{l}9.70 \\
7.93\end{array}$ & $\begin{array}{l}23.87 \\
23.43\end{array}$ & $\begin{array}{l}31.29 \\
32.67\end{array}$ & $\begin{array}{l}25.87 \\
24.88\end{array}$ & $\begin{array}{l}9.78 \\
9.83\end{array}$ & $\begin{array}{l}7.57 \\
6.58\end{array}$ \\
\hline
\end{tabular}


val. For both offenses, however, rates dedine for units exceeding a 50 percent arrest level. A somewhat similar pattern holds for counties with murder and rape rates being below total county averages for anits in the $0-25$ percent range and with generally average or above average rates for those falling in the 26-75 percent arrest range. As with robbery, however, rates of murder and rape decline after certainty exceeds 75 percent.

In sum, Table I indicates a nonlinear association between arrest and offense rates for both total and individual felonies. The form of the nonlinear relationship is not uniform, however, for each offense, with rates taking a downturn at different levels of certainty.

To further examine the certaintyrate relationship, correlations were computed between arrest and offense rates for individual and total felonies. Results of this analysis are reported for counties and cities in the last columns of Tables 2 and 3 , respectively.
As noted above, Tittle and Rowe found a product moment correlation of -.65 for counties and -.19 for cities for 1971. For 1972, the respective coefficients are $-.631(\mathrm{P}<.001)$ and $-.190(\mathrm{P}<.01)$. As Table 1 would suggest, however, the certainty-rate relationship is not uniform for each offense. For assaults, breaking and entering, larceny and auto theft, the coefficients are very comparable to those for total felonies. This is not the case for murder, forcible rape and robbery, however. of these three felonies, only the coefficient for murder (counties) is in the predicted negative direction, with the remaining correlations being positive. Even the county coefficient for murder, however, is much less substantial than that for total felonies. In short, while the findings for total felonies provide a reasonably good indicator of the certainty-rate relationship for some offenses, levels of arrest would appear much less important for those crimes commonly thonght to be least subject to deterrence (murder, rape, robbery).

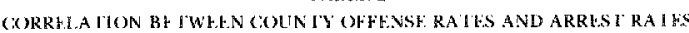

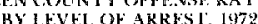

\begin{tabular}{|c|c|c|c|c|c|c|c|c|c|c|c|}
\hline \multirow{3}{*}{$\frac{\text { Offenses }}{\text { Morder }}$} & \multicolumn{10}{|c|}{ Level of Arreat } & \multirow{2}{*}{$\begin{array}{c}\text { All Countiea } \\
(0-1007) \\
\end{array}$} \\
\hline & Countles & $10 \%$ & $20 \%$ & $30 \%$ & $40 x$ & $50 \%$ & $60 \%$ & $70 \%$ & 802 & 902 & \\
\hline & $\begin{array}{c}\text { above } \\
\text { Below }\end{array}$ & .060 & $\begin{array}{r}.060 \\
.06 \\
\end{array}$ & .060 & $\begin{array}{r}.032 \\
\therefore .089 \\
.098\end{array}$ & $\begin{array}{l}.031 \\
.0997 \\
0.097\end{array}$ & $\begin{array}{r}.092 \\
.114 \\
\end{array}$ & $\begin{array}{r}1122 \\
\therefore 146 \\
1146\end{array}$ & $\begin{array}{r}.060 \\
\quad .169 \\
\end{array}$ & $\begin{array}{r}.055 \\
\therefore 187 \\
\end{array}$ & \\
\hline Forctb12 Rapa & $\begin{array}{l}\text { Sbove } \\
\text { beloge }\end{array}$ & $-\frac{.256 n}{2 x \neq m}$ & $-.236 n$ & $\begin{array}{l}-.295 \mathrm{~A} \\
-.307 \\
\end{array}$ & $\begin{array}{l}-.260 \mathrm{a} \\
-.566 \mathrm{~b} \\
\end{array}$ & $\begin{array}{l}-.204 \\
-.612 c \\
\end{array}$ & $\begin{array}{l}-.148 \\
. .623 \mathrm{c} \\
\end{array}$ & $\begin{array}{l}-.130 \\
-.348 c \\
.548 c\end{array}$ & $\begin{array}{l}.100 \\
.571 \mathrm{c} \\
.\end{array}$ & .098 & .357 \\
\hline Rotbety & $\begin{array}{l}\text { shove } \\
\text { below }\end{array}$ & -3756 & $\begin{array}{r}-.418 c \\
.362 \\
\end{array}$ & $\begin{array}{r}-.3796 \\
. .721 c \\
\end{array}$ & $\begin{array}{r}-.42 b \\
.539 c \\
\end{array}$ & $\begin{array}{l}-.4400 \\
.3958 \\
\end{array}$ & $\begin{aligned}-.399 . \mathrm{m} \\
.368 \mathrm{ab} \\
\end{aligned}$ & $\begin{array}{l}-.265 \\
-2628 \\
-2628\end{array}$ & $\begin{array}{r}-.299 \\
-219 \\
\end{array}$ & $\begin{array}{r}-.202 \\
.202 \\
\end{array}$ & .136 \\
\hline Assaule & $\begin{array}{l}\text { above } \\
\text { Belown }\end{array}$ & -.4716 & $\begin{array}{c}-4,344 c \\
\text { tath }\end{array}$ & $\begin{array}{c}-.434 \mathrm{c} \\
\text { thint } \\
\end{array}$ & $\begin{array}{r}-416 c \\
-405 c \\
\end{array}$ & $\begin{array}{r}-.315 \% \\
-., 3101 \\
\end{array}$ & $\begin{array}{r}-.156 \\
-.257 \\
\end{array}$ & $\begin{array}{l}-.023 \\
-.0386 \mathrm{~b} \\
-., 98\end{array}$ & $\begin{array}{l}-.121 \\
-.2250 \\
-.25\end{array}$ & $\begin{array}{r}-317 \\
-3998 \mathrm{C} \\
-\quad .598\end{array}$ &.- .5006 \\
\hline Breaking Entering & $\begin{array}{l}\text { above } \\
\text { beloge }\end{array}$ & $-.586 \mathrm{c}$ & $\begin{array}{r}-.489 b \\
.187 \\
\end{array}$ & $\begin{array}{r}-.637 \mathrm{~b} \\
-.495 \mathrm{c} \\
\end{array}$ & $\begin{array}{r}* \pm * \\
-, 5196 \\
\end{array}$ & 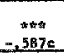 & 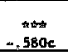 & 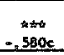 & 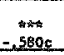 & 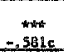 & -.581 .6 \\
\hline Larceny & $\begin{array}{l}\text { above } \\
\text { belout }\end{array}$ & $-.508 \mathrm{c}$ & 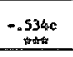 & $\begin{array}{r}-.609 \mathrm{c} \\
-.189 \\
\end{array}$ & $\begin{array}{r}-.563 \mathrm{c} \\
-.196 \\
\end{array}$ & $\begin{array}{r}-., 491 \mathrm{~b} \\
.045 \\
\end{array}$ & $\begin{array}{r}-.394 \\
-.1 B 6 \\
\end{array}$ & 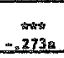 & $\begin{array}{r}\text { Ata } \\
-3016 \\
-3010\end{array}$ & 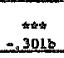 &. .4915 \\
\hline Auto Thoft & $\begin{array}{l}\text { Dibove } \\
\text { belos }\end{array}$ & $\begin{array}{c}-4688 \mathrm{e} \\
-4 \sin \\
\end{array}$ & $\begin{array}{l}-.522 \mathrm{c} \\
.259\end{array}$ & $\begin{array}{r}-4.485 \\
.092 \\
\end{array}$ & $\begin{array}{l}-.4815 \\
-.006 \\
.004\end{array}$ & $\begin{aligned} & 4.4898 \\
& \therefore-105 \\
&\end{aligned}$ & $\begin{array}{r}.50 \% a \\
\therefore .192 \\
\end{array}$ & $\begin{array}{l}-.465 \\
-.4300 \\
=+330\end{array}$ & $\begin{array}{r}-.526 \\
-.224310 \\
\end{array}$ & 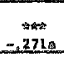 & .3296 \\
\hline Jots Eelonset & $\begin{array}{l}\text { above } \\
\text { belose }\end{array}$ & $\begin{array}{c}-.631 c^{*} \\
-.4 A k\end{array}$ & $\begin{array}{c}-662 \mathrm{c} \\
-6 \mathrm{c} \\
\end{array}$ & $\begin{array}{l}-661 c \\
-0.089\end{array}$ & $\begin{array}{l}-.593 \mathrm{~b} \\
-.232 \\
\end{array}$ & 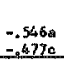 & 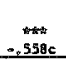 & 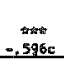 & . & 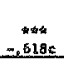 & -.6328 \\
\hline
\end{tabular}


The next stage of our analysis consisted of examining the relationship between arrest and offense rates for cities and counties falling above and below various levels of arrest. Results are reported in columns 3-11 of Tables 2 and 3.

These data reveal a picture generally consistent with deterrence theory with the exception of two offenses. For robbery, larceny and auto theft the correlations are all in the predicted negative direction for cities and counties falling above each level of clearance. For units falling below low levels of arrest the coefficients are positive, but as certainty levels increase these positive correlations are reduced in size with some becoming negative at higher levels of arrest. A similar pattern holds for assault, breaking and entering and total felonies but only for cities. In contrast, but also consistent with deterrence thcory, the county correlations for these offenses are negative (with one exception) both for units falling above and below each level of arrest.
The pattern of correlations for murder and forcible rape is generally inconsistent with the above offenses. While for murder (cities) the overall correlation between arrest and rate is positive and quite substantial $(\mathrm{r}=$ .635), the coefficients for units above each certainty level are consistently low-negative, and positive for units below each level. Examination of the scattergrams for these data reveal that the overall positive correlation between arrest and rate is a statistical artifact of a positive distribution of clusters of negatively correlated cases at each level of clearance. Examination of county correlations for murder reveals a similar statistical artifact, but with the bias in the opposite direction. Here the overall correlation for all counties is low-negative $(r=-.201)$ while the correlations for units above each certainty level are consistently low-positive.

For forcible rape, a mixed pattern results. With but two exceptions $(80 \%, 90 \%)$ the county correlations are in the predicted negative direc-

TABI.E 3 CORKLLATION BETWEF CITY OFFENSE RATES AND ARRES C RAILS BY
LEVEL OF ARRLST. 1972

\begin{tabular}{|c|c|c|c|c|c|c|c|c|c|c|c|}
\hline & \multirow[b]{2}{*}{ Clthes } & \multirow[b]{2}{*}{$10 \%$} & \multirow[b]{2}{*}{$20 \%$} & \multicolumn{2}{|c|}{ Level of Arres: } & \multirow[b]{2}{*}{$50 \%$} & \multirow[b]{2}{*}{$60 \%$} & \multirow[b]{2}{*}{$70 \%$} & \multirow[b]{2}{*}{$80 \%$} & \multirow[b]{2}{*}{$90 \%$} & \multirow{2}{*}{$\begin{array}{c}\text { ALI Citses } \\
(0-100 \%)\end{array}$} \\
\hline & & & & $30 \%$ & $40 \%$ & & & & & & \\
\hline Murder & $\begin{array}{l}\text { ebove } \\
\text { belos }\end{array}$ & $-.21 \mathrm{La}$ & $-.211 a$ & $-.231 \mathrm{a}$ & $\begin{aligned}-.191 \mathrm{~s} \\
.491 \mathrm{c}\end{aligned}$ & $\begin{array}{r}-.213 a \\
.494 c\end{array}$ & $\begin{array}{l}-.213 \mathrm{~g} \\
.494 \mathrm{c}\end{array}$ & $\begin{array}{l}-.152 \\
-.701 c\end{array}$ & $\begin{array}{l}-.215 \\
.66 \mathrm{c}\end{array}$ & $\begin{array}{l}-.222 \\
.684 c\end{array}$ & $.633 \mathrm{c}$ \\
\hline Forelble Rape & $\begin{array}{l}\text { above } \\
\text { belcys }\end{array}$ & .029 & $\begin{array}{l}.025 \\
4 \pm 0 c\end{array}$ & $\begin{array}{l}.025 \\
.519 c\end{array}$ & $\begin{array}{l}.135 \\
.697 \mathrm{c}\end{array}$ & $\begin{array}{l}.165 \\
.601 \mathrm{c}\end{array}$ & .250 & $\begin{array}{l}.218 \\
.586 c\end{array}$ & $\begin{array}{l}.478 \mathrm{~b} \\
.625 \mathrm{~s}\end{array}$ & $\begin{array}{l}.479 \mathrm{~b} \\
615 \mathrm{c}\end{array}$ & $.461 \mathrm{e}$ \\
\hline Bobbery & $\begin{array}{l}\text { above } \\
\text { belot }\end{array}$ & $\begin{array}{r}-.298 \mathrm{c} \\
.507 c \\
\end{array}$ & $\begin{array}{r}-.293 \mathrm{~b} \\
-.647 \mathrm{C} \\
\end{array}$ & $\begin{array}{r}-.299 \mathrm{~b} \\
.515 \mathrm{c} \\
\end{array}$ & $\begin{array}{l}-.293 \mathrm{a} \\
-.44 \mathrm{~B} \\
\end{array}$ & $\begin{array}{r}-.383 \mathrm{a} \\
-345 \mathrm{~s} \\
\end{array}$ & $\begin{array}{r}-.449 \mathrm{~g} \\
-.30 \mathrm{e} \mathrm{c} \\
\end{array}$ & $\begin{array}{r}-.421 .8 \\
-315 c \\
\end{array}$ & $\begin{array}{r}-441 \\
-3000\end{array}$ & $\begin{array}{l}-328 \\
-290 c \\
\end{array}$ & .082 \\
\hline$\overline{\text { Assault }}$ & $\begin{array}{l}\text { Aboue } \\
\text { belou }\end{array}$ & $\begin{array}{r}-.338 \mathrm{c} \\
-.501 \mathrm{~b} \\
\end{array}$ & $\begin{array}{r}-.321 \mathrm{c} \\
.487 \mathrm{c}\end{array}$ & $\begin{array}{r}-.2811 \mathrm{c} \\
.401 \mathrm{c} \\
\end{array}$ & $\begin{array}{r}-.272 b \\
.296 b \\
\end{array}$ & $\begin{array}{r}-.320 c \\
.1602 \\
\end{array}$ & $\begin{array}{l}-.272 b \\
-.154 \mathrm{~B} \\
\end{array}$ & -.2400 & $\begin{array}{r}-.190 \\
.046 \\
\end{array}$ & $\begin{array}{r}-.139 \\
-.034 \\
\end{array}$ & -.465 \\
\hline Breaking \& Entering & $\begin{array}{l}\text { strove } \\
\text { beloy }\end{array}$ & $\begin{array}{r}-.294 c \\
505 c \\
\end{array}$ & $\begin{array}{r}-.279 \mathrm{~s} \\
349 \mathrm{c} \\
\end{array}$ & $\begin{array}{r}-.316 \\
.1328 \\
\end{array}$ & $\begin{array}{r}m=x \\
-, 003 \\
\end{array}$ & $\begin{array}{r}* * * * \\
-0+8 \\
-0.8\end{array}$ & $\begin{array}{r}* * * \\
-.085 \\
.08\end{array}$ & $\begin{array}{r}+* * \\
-, 085 \\
-085\end{array}$ & $\begin{array}{r}* * * \pi \\
-1468 \mathrm{a} \\
\end{array}$ & $\begin{array}{r}* * * \\
-1464 \\
\end{array}$ & -.165 \\
\hline Lerceny & $\begin{array}{l}\text { bove } \\
\text { below }\end{array}$ & $\begin{array}{l}-.287 \\
.7099_{c}\end{array}$ & $\begin{array}{r}-.2150 \\
-.59 c \\
\end{array}$ & $\begin{array}{r}-3050 \\
.209 a \\
\end{array}$ & $\begin{array}{r}. .3600 \\
.056 \\
.056\end{array}$ & $\begin{array}{r}-.368 \mathrm{~b} \\
-.078 \\
\end{array}$ & $\begin{array}{r}-.455 \mathrm{c} \\
-.003 \\
\end{array}$ & $\begin{array}{r}-.411 \\
.046 \\
\end{array}$ & $\begin{array}{r}. .4636 \\
-.005 \\
. .005\end{array}$ & $\begin{array}{r}-.496 \mathrm{a} \\
-.022 \\
\end{array}$ & $-.204 \mathrm{~b}$ \\
\hline Auto Theft & $\begin{array}{l}\text { Above } \\
\text { belou }\end{array}$ & $\begin{array}{r}-.387 \mathrm{c} \\
-319 \mathrm{c} \\
\end{array}$ & $\begin{array}{r}-.429 \mathrm{e} \\
-.340 \mathrm{c}\end{array}$ & $\begin{array}{r}-.327 \mathrm{a} \\
-.334 \mathrm{c} \\
\end{array}$ & $\begin{array}{r}-.196 \\
-.257 c \\
\end{array}$ & $\begin{array}{r}-.557 \mathrm{~s} \\
-.081 \\
\end{array}$ & $\begin{array}{c}t \rightarrow * \\
072 \\
\end{array}$ & $\begin{array}{l}\text { \#\#* } \\
.037 \\
\end{array}$ & 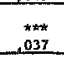 & $\begin{array}{r}744 \\
.037 \\
.037\end{array}$ &. .040 \\
\hline Fotal Fe_onles & $\begin{array}{l}\text { Above } \\
\text { belou }\end{array}$ & $\begin{array}{r}-.277 \mathrm{t} \\
.583 \mathrm{~b}\end{array}$ & $\begin{array}{r}. .364 \mathrm{c} \\
.287 \mathrm{~b}\end{array}$ & $\begin{array}{c}. .432 c \\
.089\end{array}$ & $\begin{array}{c}-.5000 \\
.167\end{array}$ & $\begin{array}{c}-.568 \mathrm{~b} \\
.111\end{array}$ & $\begin{array}{r}. .452 \\
.061\end{array}$ & $\begin{array}{r}-.219 \\
.073\end{array}$ & $\begin{array}{r}.0210 \\
.047\end{array}$ & $\begin{array}{r}\$ * \\
., 05 ?\end{array}$ & $-.190 b$ \\
\hline
\end{tabular}

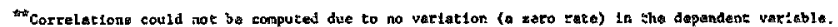

Corralations aza sot somputed sos in bizze batow 10 .

$\triangle=P<.05$

$3=9<$, or

$\therefore \leq<.009$ 
tion for cases above each level of certainty, with all coefficients being positive for units falling below each level. Unlike robbery, larceny, auto theft, assault (cities only) breaking and entering and total felonies (cities only), however, the size of these positive correlations is not reduced as certainty increases, nor do they become negative at higher levels of arrest.

Finally, for cities the pattern of positive correlations for forcible rape is completely contrary to deterrence theory. For units falling above each level of certainty, the correlations increase in size and do not decrease as the level of arrest increases. In addition, like murder (cities only), the size of the positive correlations for units below each level of certainty is not reduced as level of arrest increases.

The final stage of our analysis consisted of examining the relationship between arrest rates and offense rates controlling for the level of police (number of police per 1000 population). As noted above, by comparing the zero-order correlations between the rate variables with the partial coefficients that result when the police variable is introduced, we will be able to examine the possible spuriousness of the certainty-offense rate relationship. Table 4 reports the results of this analysis.

If the zero-order arrest offenserate coefficients (columns 2 and 4 ) are a statistical artifact of not controlling for police manpower, then controlling for this third variable should reduce the size of the coefficients (columns 3 and 5). If on the other hand, the certainty-rate relationship is independent of the level of police manpower, the coefficients should remain unchanged. For both counties and cities, Table 4 shows the zeroorder and partial coefficients to be very similar in size. For counties, with the exception of Corcible rape and robbery, the correlations are slightly reduced when the police variable is considered. For forcible rape, the positive coefficient $(r=.157)$ slightly increased $(r=.260)$ when the control

TABLE 4

ZERO-ORDER AND PARTIAL CORRELATIONS BETWEEN COUNTY AND CITY ARREST RATES AND OFFENSE RATES, 1972

\begin{tabular}{|c|c|c|c|c|}
\hline \multirow[b]{2}{*}{ Offense } & \multicolumn{2}{|c|}{ Counties } & \multicolumn{2}{|c|}{ Cities } \\
\hline & $\begin{array}{c}\text { Zero-Order } \\
\text { r }\end{array}$ & $\underset{r}{\text { Partial }}$ & $\begin{array}{c}\text { Zero-Order } \\
\text { r }\end{array}$ & $\begin{array}{l}\text { Partial } \\
\mathrm{r}\end{array}$ \\
\hline Murder & $-.201 a$ & -.184 & $.635 \mathrm{c}$ & $.640 \mathrm{c}$ \\
\hline Forcible Rape & .157 & $.260 \mathrm{a}$ & $.46 \mathrm{lc}$ & $.457 c$ \\
\hline Robbery & .136 & -.036 & .082 & .063 \\
\hline Assault & $-.500 c$ & $-.430 \mathrm{c}$ & -.165 & $-.163 \mathrm{a}$ \\
\hline Breaking \& Entering & $-.581 \mathrm{c}$ & $-.509 c$ & -.165 & $-.175 b$ \\
\hline Larceny & $-.491 \mathrm{c}$ & $-.396 c$ & $-.204 b$ & $-.223 c$ \\
\hline Auto Theft & $-.329 b$ & $-.270 \mathrm{a}$ & -.040 & -.055 \\
\hline Total Felonies & $-.631 c$ & $-.537 c$ & $-.190 b$ & $-189 b$ \\
\hline
\end{tabular}

$$
\begin{aligned}
& a=p<.05 \\
& b=p<.01 \\
& c=p<.001
\end{aligned}
$$


variable is introduced, while for robbery, the correlation changes from a positive $(r=.136)$ to a negative sign $(\mathrm{r}=-.036)$.

For cities a somewhat similar pattern results. While for four offenses (forcible rape, robbery, assault, total felonies) the partial correlations are slightly smaller than their zero-order counterparts, just the opposite occurs for the remaining offenses (murder, breaking and entering, larceny, auto theft) when the control variable is introduced. In all cases, however, the bivariate and partial correlations are very similar in size, and like the county data, tests of significance show the two sets of coefficients not to differ significantly $(P<.05)$ for any offense. Accordingly, we may reject the hypothesis that the observed relationship between arrest rates and of fense rates is spuriously produced by the level of the police in a community.

\section{Summary and Conclusion}

In this investigation we have attempted to build upon some of the limitations of Tittle and Rowe's examination of the role of legal sanctions as a deterrent to crime. As in their analysis, we examine the effect of arrest on total felony rates and attempt to identify the level of certainty (apprehension) required to reduce rates. Second, to examine the argument that some crimes are more subject to deterrence than others, the effect of certainty is examined separately for seven major felonies to determine the level of arrest required to reduce rates for each offense. Finally, a measure of police manpower is introduced as a control variable to test for the possible spuriousness of the certainty of arrest-offense rate results.

Both our findings and Tittle and Rowe's lend support to the argument that the law-the threat of legal sanctions-can no longer be ignored in considerations of the etiology of crime. As expected, however, our data indicate that the threat of arrest does not have a uniform deterrent effect for all felonies. For offenses commonly considered to be "instrumental" in nature, arrest would appear to be a much more important determinant of the level of crime than for "expressive" crimes (Chambliss, 1967). This finding is quite consistent with the deterrerce argument for, as Tittle and Rowe (1974, 460) point out, "classical criminologists recognized that the motivation to engage in various acts differs as does the motivation of different individuals with respect to the same act."

In conclusion, the investigation reported here permits a more refined examination of the deterrence question than that provided by Tittle and Rowe and lends additional support to their argument that more attention needs to be focused upon restraint factors in deviance theory. As they also point out, however, many factors remain to be examined in developing a better understanding of deterrence. We consider this investigation as but one step in this direction and urge others to continue to explore this important area. 


\section{REFERENCES}

Andenaes, Johamnas.

1974 Punishment And Deterrence. Ann Arbor: The University of Michigan Press.

Bailey, William C., J. D. Martin, and L. N. Gray.

1974 "Crime and Deterrence: A Correlation Analysis." Joumal of Research in Crime and Delinquency 11 (July):124-143.

Bailey, William C., L. N. Gray, and I. D. Martin.

1971 "On Punishment and Crime (Chiricos and Waldo): Some Methodological Commentary." Social Problems 19 (Fall): 284-289.

Bailey, William C. and Ronald W. Smith.

1972 "Punishment: It Severity and Certainty." Joumal of Criminal Law, Criminology and Police Science 63(4):530-539.

Chambliss, William I.

1967 "Types of Deviance and the Effectiveness of Legal Sanctions." Wisconsin Law Review (Summer):703-719.

Chiricos, Theodore $G$. and Gordon P. Waldo.

1970 "Punishment and Crime: An Examination of Some Empirical Evidence." Social Problems 18 (Fall):200-217.

Florida Department of Law Enforcement 19721972 Annual Repont: Crime In Florida. Tallahassee, Hlorida.

Gibbs, Jack $\mathrm{P}$.

1968 "Crime, Punishment and Deterrence." Social Science Quarterly 49 (September):289-395.

Gray, Louis N. and J. D. Martin.

1969 "Punishment and Deterrence: Another Analysis of Gibbs' Data." Social Science Quarterly 50 (September):289-295.

Logan, Charles H.

1972 "General Deterrent Effects of Imprisonment." Social Forces 51 (September):64-73.

Logan, Charles $\mathrm{H}$.

1971 "On Punishment and Crime (Chiricos and Waldo): Some Methodological Commentary." Social Problems 19 (Fall):280-284.

Tittle, Charles R.

1975 Information from a conversation with the author, American Sociological Association Meetings, San Francisco, California, August 26, 1975.

Tittle, Charles R.

1969 "Crime Rates and Legal Sanctions." Social Problems 16 (Spring):409-423.

Tittle, Charles R. and Alan R. Rowe.

1974 "Certainty of Arrest and Crime Rates: A Further Test of the Deterrence Hypothesis." Social Forces 52 (June):455-462.

Zimring, Frank.

1971 Perspectives on Deterrence. Public Health Service Publication, No, 2056, NIMH Center for Studies of Crime and Delinquency, U.S. Govermment Printing office.

Zimring, Frank and Gordon Hawkins.

1973 Deterrence: The Legal Threat in Crime Control. Chicago: The University of Chicago Press. 